\title{
Notes on Zenker's Organs in the Ostracod Candona
}

\author{
Robert $V$. Kesiing \\ University of Michigan, Ann Arbor
}

Male ostracods of Candona and other genera of the family Cyprididae have paired ejaculatory apparatus, commonly called Zenker's organs. These distinctive, voluminous organs lie in the posterodorsal part of the body, one on each side (fig. 8). Each Zenker's organ consists of a central tube, several wreaths of chitinous spines, numerous tiny muscles, and a surrounding cylinder of epithelial tissue. The central tube is composed of epithelium reinforced with numerous hollow chitin rings, closely spaced but allowing the organ to be shortened by contraction of the muscles. Several wreaths of radiating chitin spines are attached to the central tube and laced together by an intricate set of very small muscles. The front and rear wreaths, which form the two ends of the cylindrical organ, are more complex than the others and have funnel-shaped indentations. The central tube is part of the vas deferens. In copulation, the muscles rhythmically contract in sequence to draw the spines together, shorten the central tube, and force the very long spermatozoa through the organ and out of the penis.

The male sex system, of which the Zenker's organs are integral parts, is rather complex in cypridid ostracods. Each half of the system is complete and lies on one side of the median plane; it is approximately a mirror image of the half on the opposite side, but is in no way connected to it.

To show the relationship of Zenker's organ to other male sex organs, one half of the system is here described briefly. The four testes lie in the hypodermis, a thin flap of tissue which spreads out from the side of the body and lines the valve. They are parallel and, from their syncytia in the posterior part of the hypodermis, curve downward, forward, and upward (fig. 9). At their entrance into the body, the testes unite to form a vas deferens, which has a devious circuit. The vas deferens re-enters the hypodermis at the side of the forehead, curves parallel to the free edge of the valve, and ends blindly in the posterodorsal region. Upon reaching the blind end, spermatozoa reverse their direction and retrace their route to the ventral region where they enter a second branch of the vas deferens, which parallels the first along the anterior margin of the hypodermis (fig. 9). The vas deferens then extends to the rear of the body, loops back and forth a few times, encircles the Zenker's organ, and en!arges to form a seminal vesicle. Zenker's organ lies immediately behind the seminal vesicle (figs. 8-9). It surrounds a short section of the vas deferens. From the rear of the organ a very narrow tube leads into the intricate penis, in which it makes a more or less S-shaped circuit, marked by several enlargements. It terminates at the tip of the inner lobe of the large penis (fig. 9).

\section{PREVIOUS WORK}

Although Zenker's organs have been known for more than a century, there have been many conflicting interpretations of their structure and function. Several statements that were true were denied by later authors. Only the

Reprinted from

\section{THE AMERICAN MIDLAND NATURALIST}

Vol. 57, No. I, pp. 175-182, January, 1957 
highlights of the published accounts and selected quotations are given here on the important discoveries and ideas concerning these unusual organs.

Perhaps the first mention of these organs was by Ramdohr (1808), who mentioned "längliche, dunkle, der Länge nach gefranzte und in eine weite durchsichtige walzenförmige Membran eingeschlossene Körper." Much of Ramdohr's work was later discounted because he described both male and female organs as though they were from one animal. If we regard his observations as compilations from many specimens, however, it becomes clear that he was the first to isolate and describe many anatomical features of ostracods. His Plate 3, fig. 10, leaves little doubt, at least in my mind, that he actually saw these organs, although he showed them connected to the third thoracic legs.

Zenker was the first worker to investigate in detail the male and female sex systems in ostracods and the first to give a lucid account of the organs that bear his name. In 1850 he called each of the organs a "glandula mucosa" in the belief that it supplied a secretion to the penis. In his Plate 5, fig. 1, he illustrated the vas deferens and Zenker's organ independently leading into the penis. Despite his misinterpretation of the function and anatomical connection of the organ, Zenker gave an excellent description. He discovered the central tube, seven wreaths of radiating chitin spines, and the outer cylinder. He wrote (p. 196) :

Seine Axe wird von einem engeren Cylinder gebildet, von dem ein Ausführungsgang zum Penis führt. Von der Axe aus strahlen an den äusseren Cylinder 7 scheibenförmige System von Borsten, in gleichen Abständen. Das erste und letzte, die die beiden CylinderGrundflächen bilden, sind aus mehreren Schichten von Borsten zusammengesetzt, die inneren 5 sind einfacher gebaut.

In 1853 Lilljeborg called the organ a "materia carnosa." He remarked that the "glandula mucosa" of Zenker did not have a separate duct leading into the penis but that the vas deferens passed through it. Furthermore, he noted that the larger cylinder contained muscles instead of glands.

In his comprehensive monograph of 1854 , Zenker added to his previous description of the organ that the inner cylinder consisted of chitin rings. Evidently Zenker was unaware of Lilljeborg's publication of the preceding year, for he did not comment on it. He referred to the organ as "Schleimdrüse (glandula mucosa)" and reiterated his belief that it contained glandular cells. Zenker saw stripes parallel to the axis, which he interpreted as chitin; there can be little doubt that they were muscles.

Leydig (1860) at first thought the organ, which he called an "accessorische Geschlechtsdrüse," might be similar to the accessory sex glands in some insects, in which the one-celled glands open through chitin ducts into a central chitin canal. However, he discounted this theory when he found muscles but no glands in the organ. He did not suggest a specific function.

Weismann (1880), in his very brief but informative paper on parthenogenesis in Cyprididae, was the first to decipher the use of the organs. He concluded that each was a remarkable kind of ejaculatory apparatus and part of the vas deferens. He stated (p. 84):

So ist die kolossale sog. "Schleimdrüse," welche Zenker bei den Männchen der Cypriden beschrieb, keine Drüse, sondern ein höchst merkwürdiger Ejaculationsapparat. Er hängt nicht seitlich dem $V$ as deferens an, sondern ist in den Verlauf desselben eingeschaltet. 
In 1880, the year that Weismann's article appeared, G. Wilhelm Müller followed the interpretation of Zenker and called the organs "Schleimdrüse." In 1884, Müller again expressed his belief that they were mucous glands, and emphatically stated that Weismann was incorrect. He seems to have had some doubt about the position of Zenker's organ in the male reproductive system, for he said that the relationship of the vas deferens to the penis was not known with certainty although the "Schleimdrüse" emptied through the penis.

Rehberg (1884) concluded the organ was too rigid to act as an ejaculator, and suggested that it was an armored seminal receptacle for protection of the spermatozoa against pressure exerted by closing of the valves.

Most writers after Rehberg have agreed with Weismann. Nordqvist (1885) described details based on sections through the "Ejakulationsapparat." Stuhlmann (1886) gave a full and essentially correct account of the male sex system, and also referred to the organ as an ejaculation apparatus. Schwarz (1888) believed that it functioned as a "Sämenpumpe" in "Cyprois" (Notodromas) and probably in Candona, but that in other ostracods it was an incompressible vestigial organ in which the epithelium produced a secretion. He thought in Notodromas the forked spines served to lengthen the central tube and the muscles to shorten it again.

In 1889 Müller called it a "Ductus ejaculatorius." In 1894 he apologized for his 1880 and 1884 articles, stating that they served only to warm up the error of Zenker. He described in detail the construction and action of the organ in several groups of ostracods.

Vávra $(1891$, p. 23) gave the organ its common name: "Als 'Zenker'sche Organ' bezeichne ich jenen Theil des Samenleiters, den Zenker als 'glandula. mucosa' beschrieb. . "He agreed with Schwarz that it was a functional ejaculator in Notodromas and vestigial in other genera.

Claus (1890) endorsed the conclusions of Weismann and his students, Stuhlmann and Nordqvist. He later (1893) referred to the organ as an ejaculation apparatus, and noted correctly that in Candona the organs are related to dimorphic differences in shape of the valves. Later writers did not add to our understanding of the Zenker's organs, and simply reviewed the old literature.

In zoological literature there are four statements about Zenker's organ which have been generally accepted, but which I have found to be false or to have exceptions. These statements express (1) that the enlargement of the vas deferens, which I call the seminal vesicle, is not immediately in front of Zenker's organ, (2) that spermatozoa do not lie in Zenker's organ except during ejaculation, (3) that only one spermatozoon enters Zenker's organ at a time, and (4) that each organ in ostracods of the genus Candona has seven wreaths of chitinous spines.

\section{Seminal Vesicles}

Zenker noted an enlargement of the vas deferens in 1850. He stated ( $p$. 195), "Die 5 Hodenschläuche münden in einen Becher aus, der in die Mitte des Rückens liegt. Er verläuft, nur wenig verengt als Samenleiter dem Schwanze zu, so dass er nur als eine Erweiterung desselben zu betrachten ist." It should be explained that Zenker counted the blind section of the vas deferens as a fifth testicle. He showed (in his Pl. 5, fig. 1) the four testes and the 


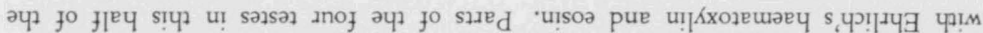

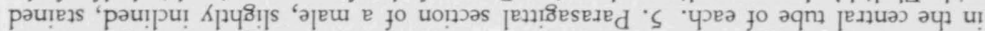

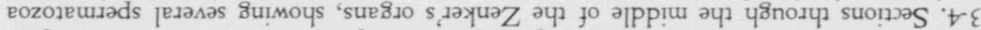

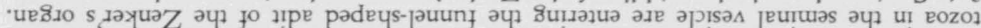
- eunads әчз '

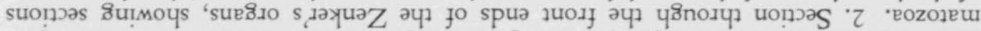

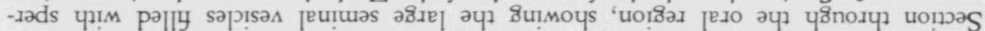

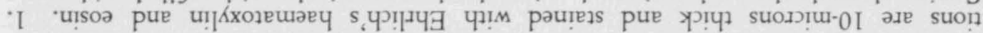

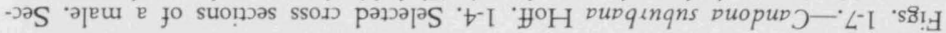
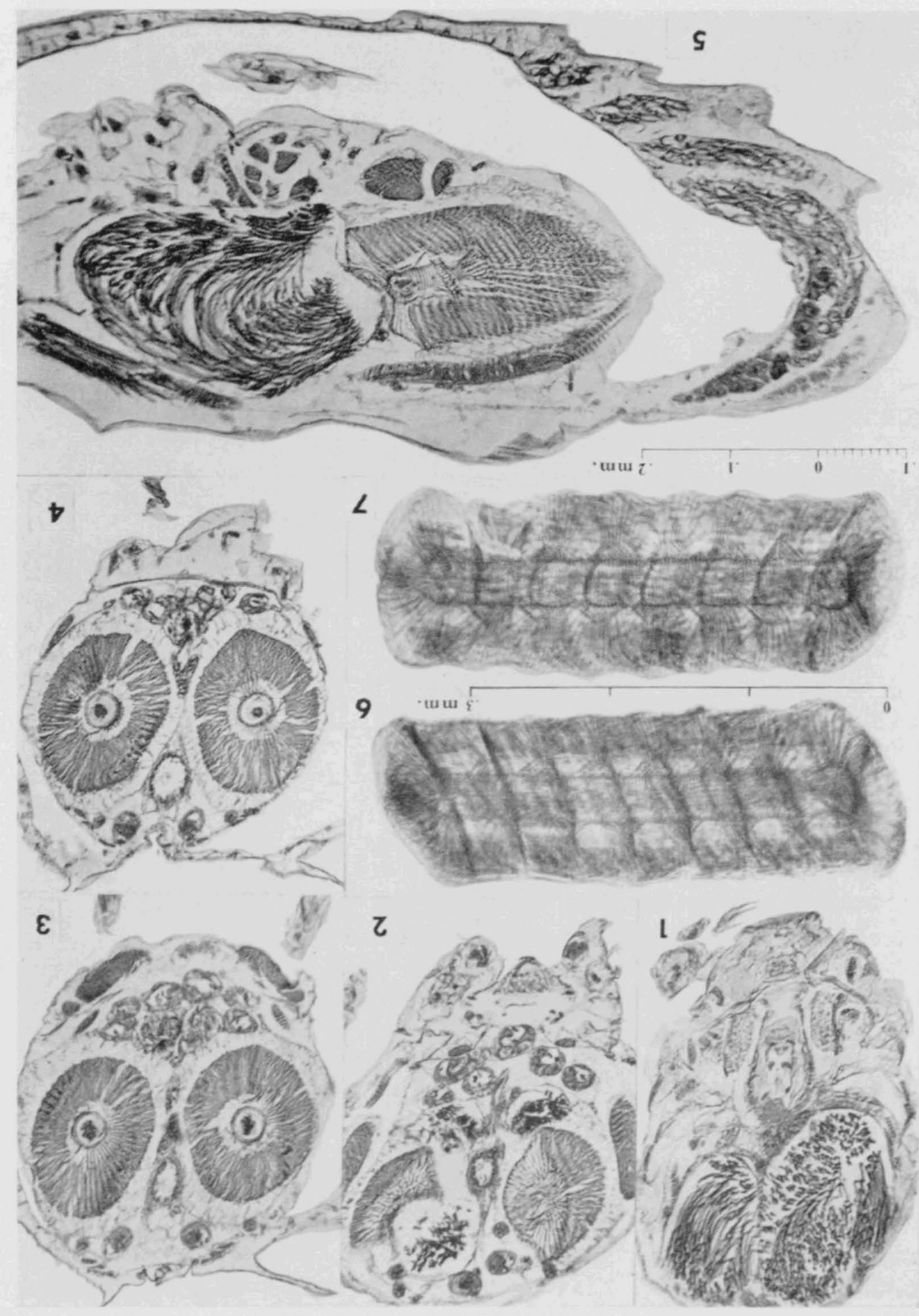

(I) $\angle S$ 
blind section of the vas deferens joined to an enlargement of the vas deferens, which continued as a narrower tube to the penis; in this illustration Zenker's organ was connected separately to the penis.

It was Stuhlmann (1886, p. 549) who first gave a good description of the seminal vesicle in Cyprididae, when he wrote:

Das Vas deferens mündet in das proximale Ende des Ejaculationsapparates ein. Bei Cyprois ist diese Verbindung ziemlich leicht zu sehen, weil hier das $V$ as deferens sich oft stark erweitert und die Spermatozoen, welche wahrscheinlich nur einzeln den Ejaculationsapparat passiren können, sich hier, wie in einer Art von Samenblase anhäufen; man sieht dann deutlich, wie dieselben in einem dicken Bündel in den oberen Trichter des Ejaculationsapparates hineindringen.

Nevertheless, Stuhlmann's contribution was ignored and G. W. Müller figured (1889, Pl. 32, fig. 6; 1894, unnumbered text fig.) the wide part of the vas deferens as preceding both the blind section of the vas deferens and the Zenker's organ. His "birnförmige Erweiterung" was shown as a vesicle near the junction of the testes. Müller's 1894 figure was reproduced by Klie (1926, fig. 20). Other writers have not mentioned a wide section of the vas deferens.

In Candona suburbana Hoff (fig. 1) the seminal vesicles are remarkably large. They are distended with spermatozoa and occupy one-eighth of the bcdy. Their anterior ends reach nearly to the wall of the forehead (fig. 8). As shown in figs. 2 and 5, the posterior end of each seminal vesicle lies in the funnel-shaped indentation of the Zenker's organ. There is no narrow section of the vas deferens between the seminal vesicle and Zenker's organ in any of the 25 specimens of Candona which I have examined in detail.

\section{Spermatozoa in Zenker's Organs}

Writers disagree as to whether spermatozoa normally lie in Zenker's organ. Rehberg (1884, p. 15) said, "Der innere Cylinder ist, wie man es leicht beim Auseinanderziehen der Chitinkränze wahrnehmen kann, mit Spermatozoen angefüllt." Nordqvist, however, denied that spermatozoa enter the organ except during copulation. He wrote (1885, p. 162), ". . . der Apparat, wenn das Thier nicht in Kopulation begriffen ist, nie Spermatozoen enthält."

As can be seen in figs. 3-4, Zenker's organs contain spermatozoa. In six males of Candona suburbana which were sectioned, each Zenker's organ had several spermatozoa within it. The animals were not in copulation when killed, so that spermatozoa in the organ seem to be the normal condition, at least within this species. It seems highly unlikely that in each specimen which was sectioned the spermatozoa could have been forced through the small opening and into Zenker's organ by the embedding and sectioning process.

Another question concerns the number of spermatozoa in Zenker's organ

animal can be seen in the hypodermis. The seminal vesicle, distended with spermatozoa, enters the front end of Zenker's organ, which is incomplete in this section. In Zenker's organ parts of five wreaths of chitin spines, the chitin rings of the central tube, and the muscles can be seen. 6-7.-Candona fossulensis Hoff. Zenker's organs from Paratype TL25, collection of the late Dr. Harley J. Van Cleave, mounted in diaphane and stained with acid fuchsin (?). Each of these organs contains eight wreaths of chitin spines. The chitin rings around the central tube show up in these photographs.

(Figs. $1-5$ to scale shown in fig. 5 ; figs. 6.7 to scale shown between them.) 


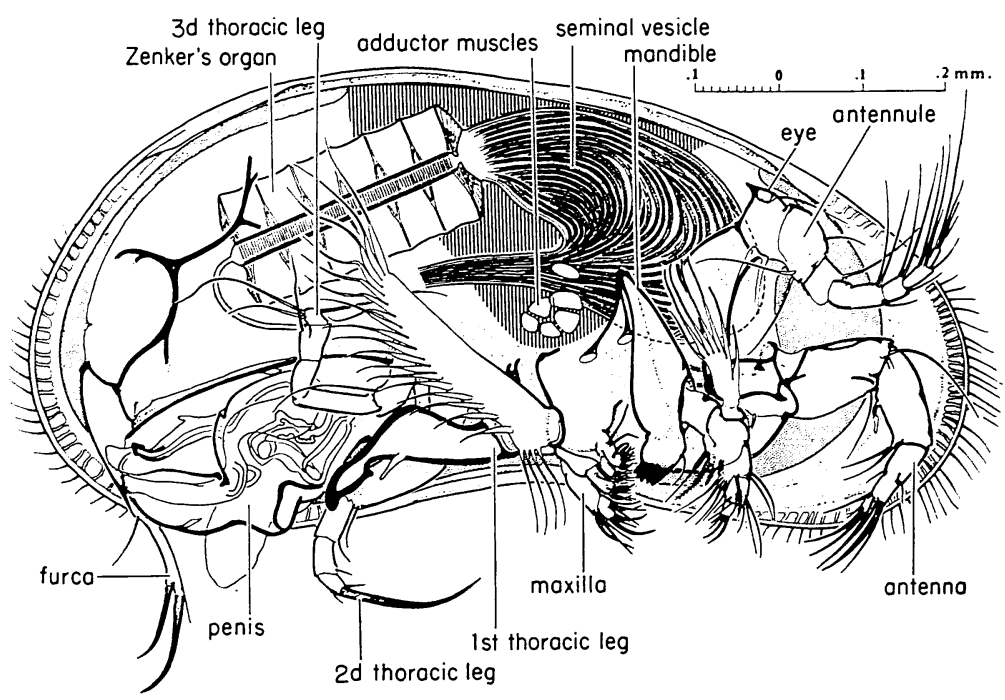

Fig. 8.-Candona suburbana Hoff. Male with right valve and part of the body wall removed to show the body, appendages, seminal vesicle, and Zenker's organ on the right side. The vertically hatched area represents the junction of the body wall and the hypodermis.

at one time. Weismann (1880) thought that the narrow anterior opening would admit only one spermatozoon at a time. Nordquist (1885, p. 163) stated positively, ". . . nur ein Spermatozoon auf einmal in den Apparat eindringen kann." Schwarz (1888) believed that a major function of the organ was to isolate spermatozoa and allow them to pass one at a time.

Figs. 3-4 shows several spermatozoa within each organ. Whether they enter singly or not, I cannot say, but certainly more than one lies in the organ at one time.

\section{- Number of Wreaths in Candona}

There is no statement published that male ostracods of the genus Candona have more or fewer than seven wreaths of chitinous spines in each of the Zenker's organs. The number seven has been stated by Zenker $(1850 ; 1854)$, Rehberg (1884), Vávra (1891), Klie (1926), and others. Sars (1923) considered seven wreaths in Zenker's organ to be a generic character of Candona. It is true that Klie (1938) said that the organ in the subfamily Candocyprinae, to which he assigned Candona, had six to eight wreaths, but he gave no number for the genus. Similarly, Hoff $(1942$, p. 53) stated that the subfamily Candoninae had males "usually with seven wreaths of chitinous spines," but gave no additional information for Candona or its speceis.

One specimen has come to my attention in which the Zenker's organs each have eight wreaths (figs. 6-7). It is a paratype of Candona fossulensis Hoff. Hoff deposited this type in the care of the late Dr. Harley J. Van Cleave, 


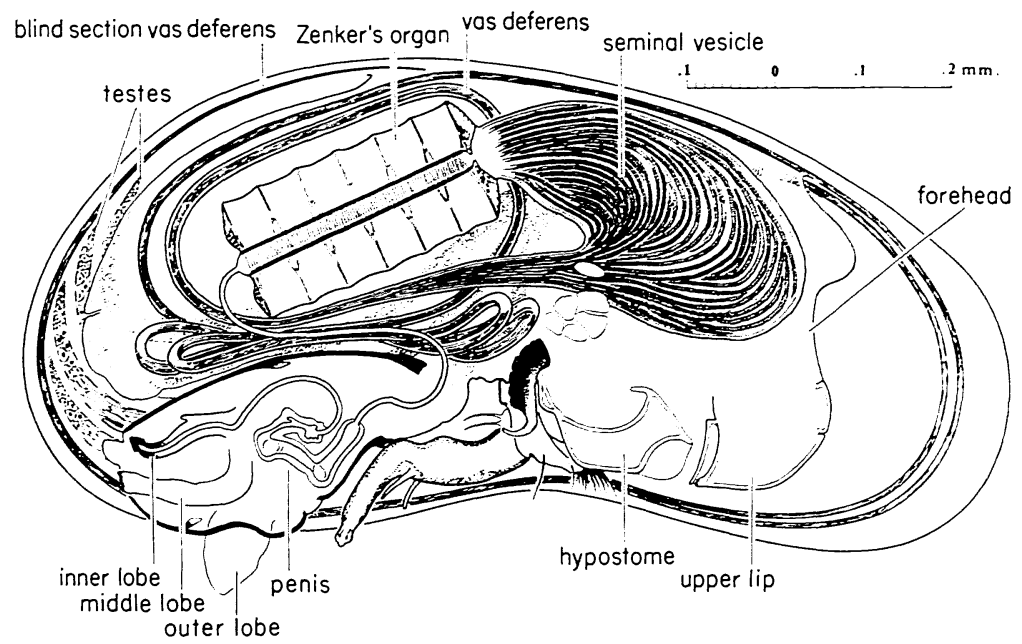

Fig. 9.-Candona suburbana Hoff. Male cut along the median sagittal plane to show the sex system in the left half of the animal. The Zenker's organ is cut in half to show the central tube.

through whose courtesy I studied it in 1948. Although the supernumerary wreath in each of the organs must be regarded as an abnormality, its occurrence casts some doubt on the significance of the number of wreaths as a generic or subfamilial character.

Acknowledgments.-I am greatly indebted to the late Dr. Harley J. Van Cleave of the University of Illinois, under whose direction this study was started in 1948. His enthusiastic support and encouragement contributed much to the ideas presented above. Shortly before his death, Dr. Van Cleave offered valuable criticism of the preliminary draft of this paper.

I wish to express my thanks to Miss Marion Birkner, University of Illinois, who, in 1948, prepared the sections illustrated in the plate.

\section{REFERENCES}

Claus, C. C. 1890-Über die Organisation der Cypriden. K. Akad. Wiss. Wien. $1890: 55-60$.

1893-Beiträge zur Kenntniss der Süsswasser-Ostracoden, I. Über den Körperund Gleidmassenbau der Cypriden nebst Bemerkungen über einzelne innere Organe derselben. Arb. Zool. Instit. Univ. Wien Zool. Stat. Triest 10:147-216.

Hoff, C. C. 1942-The Ostracods of Illinois, Their Biology and Taxonomy. Ill. Biol. Monogr. 19:1-196.

Klie, Walter 1926-Ostracoda. Muschelkrebse. Biol. Tiere Deutschl. 16:1-56.

1938-Ostracoda, Muschelkrebse. Tierwelt Deutschl. u. angrenz. Meeresteile $34(3): 1.230$.

Leydig, F. 1860-Naturgeschichte der Daphniden (Crustacea Cladocera). Tübingen: H. Laupp'schen Buchhandlung.

Lilljeborg (Liljeborg). Wilhelm 1853-De Crustaceis ex Ordinibus Tribus: Cladocera, Ostracoda et Copepoda, in Scania Occurentibus. Om de inom Skane förekommande crustaceer af ordningarne Cladocera. Ostracoda och Copepoda. Lund: Berlingska Boktryckeriet. 
Müller, G. W. 1880-Beitrag zur Kenntniss der Fortpflanzung und der Geschlechtsverhältnisse der Ostracoden. Z. Naturw. (Ser. 3) 5:221-246.

-1884-Zur näheren Kenntniss der Cytheriden. Arch. Naturgeschichte 50:1-18.

-1889-Die Spermatogenese der Ostracoden. Zool. Jahrb. Abt. Anat. Ontog. Thiere 3:677-726.

1894-Die Ostracoden des Golfes von Neapel und der angrenzenden MeeresAbschnitte. Naples, Staz. Zool., Fauna u. Flora d. Golfes von Neapel 21:1-404.

NoRDQVIST, O. 1885-Beitrag zur Kenntniss der inneren männlichen Geschlechtsorgane der Cypriden. Acta Soc. Sci. Fenn. 15:129-168.

Rampohr, F. A. 1808-Über die Gattung Cypris Müll. und drei zu derselben gehörende neue Arten. Mag. Gesell. naturf. Freunde Berlin 2:83-93.

RehberG, G. 1884-Beiträge zur Naturgeschichte niederer Crustacean. Abh. naturw. Ver. Bremen 9:1-18.

SARs, G. O. 1923-Ostracoda, Pts. 3-4. Polycopidae (concluded), Cytherellidae, Cypridae (part). An Account of the Crustacea of Norway 9:33-72. Bergen Museum.

SCHwarTZ, C. G. 1888-Über die sogennante "Schleimdrüse" der männlichen Cypriden. Ber. naturf. Gesell. Freiburg i. B. 3:133-158.

Stuhlmann, F. 1886-Beiträge zur Anatomie der inneren männlichen Geschlechtsorgane und zur Spermatogenese der Cypriden. Z. Wiss. Zool. 44:536-569.

VÁvra, W. 1891-Monographie der Ostracoden Böhmens. Arch. přir. výzkum Čech. (Archiv naturw. Landesdurchf. Böhmen) 8:1-116.

Weismann, August 1880-Parthenogenese bei den Ostracoden. Zool. Anz. 3:82-84.

Zenker, W. 1850-Über die Geschlechtsverhältnisse der Gattung Cypris. Arch. Anat. Physiol. Wiss. Med. 1850:193-202.

1854-Monographie der Ostracoden. Arch. Naturgeschichte 20:1-87. 